\title{
CARBONATION-CORROSION RESISTANT BEHAVIOUR OF CORROSION-RESISTANT STEEL CR1OMO1 AND ITS PROTECTION MECHANISM
}

\author{
Z.Y. AI 1, 2, J.Y. JIANG1, 2, W. SUN1, 2, D. SONG1, 2, 3, H. MA4, J.C. \\ ZHANG4 \\ 1 SCHOOL OF MATERIALS SCIENCE AND ENGINEERING, SOUTHEAST UNIVERSITY, \\ NANJING 211189, JIANGSU, CHINA \\ 2 JIANGSU KEY LABORATORY OF CONSTRUCTION MATERIALS, NANJING 211189, \\ JIANGSU, CHINA \\ 3 COLLEGE OF MECHANICS AND MATERIALS, HOHAI UNIVERSITY, NANJING 210098, \\ JIANGSU, CHINA \\ 4 RESEARCH INSTITUTE OF JIANGSU SHASTEEL IRON AND STEEL, ZHANGJIAGANG \\ 215625, JIANGSU, CHINA \\ CORRESPONDING AUTHOR AT: SCHOOL OF MATERIALS SCIENCE AND ENGINEERING, \\ SOUTHEAST UNIVERSITY, NANJING 211189, JIANGSU, CHINA. TEL.: +86 02552091084 ; E- \\ MAIL ADDRESS: JIANGJINYANG16@163.COM (J. Y. JIANG)
}

\begin{abstract}
KEYWORD: CORROSION-RESISTANT STEEL; CARBONATION; PASSIVE FILM; MECHANISM ABSTRACT: The electrochemical response of new alloy corrosion-resistant steel Cr10Mo1 passivated under attack of carbonation ( $\mathrm{pH}$ from 13.3 to 9.0), was evaluated by electrochemical techniques (linear polarization resistance, and electrochemical impedance spectroscopy). X-ray photoelectron spectroscopy (XPS) was used to characterize the composition and structure of the surface film on the steel. The results show that as carbonation progressing, the corrosion-resistant steel never goes to corrosion domain even when $\mathrm{pH}$ falls to 9.0 , but has an increasing corrosion resistance. According to XPS analysis, the passive film on the corrosion-resistant steel presents a bilayer structure: an outer layer enriched in Fe oxides and hydroxides, and an inner layer rich in $\mathrm{Cr}$ species. As the $\mathrm{pH}$ decreases, Fe oxides gradually decompose while more stable and protective $\mathrm{Cr}$ oxides get enriched in the film. Under carbonation attacking, the increasing $\mathrm{Cr}$ oxides in the film act as a protection barrier to the steel corrosion and support the corrosion-resistant steel still good passivity.
\end{abstract}

\section{INTRODUCTION}

As is widely recognized, steel corrosion in reinforced concrete structures exposed to severe environments is a serious issue [1,2], which significantly reduces durability and service life of civil structures. For this problem, various coping approaches have been applied, such as increasing concrete cover quality and thickness, using coating steel rebar (galvanizing rebar, epoxy coated steel reinforcement, et al), incorporation of inhibitors during concrete mixing, electrochemical protection (including cathodic protection, electrochemical realkalization and electrochemical chloride extraction) $[2,3]$. However, these techniques and methods are all subject to certain limitations, failing to prevent steel corrosion for enough long term and more efficient solutions are required.

One of the most reliable methods for ensuring the durability of reinforced concrete structures in severe conditions is to use anticorrosive alloyed steels. Alloy corrosion-resistant steel, which has considerably high corrosion resistance but is more attractive economy than stainless steel, becomes increasingly popular. Some typical corrosion-resistant steel products have already come out, such as MMFX Steel [4], Mariloy steel [5] and fine-grained $\mathrm{Cu}-\mathrm{Cr}-\mathrm{Ni}$ alloy steel [6]. However, these steels are difficult to ensure long enough service life (75 to 100 years) for concrete structures in aggressive environments. 
In recent years, Research Institute of Jiangsu Shasteel Iron and Steel prepared out a new steel product "Cr10Mo1", alloyed with Cr about 10 wt.\% and Mo about 1wt.\%, consisting of granular bainite with ferrite between the grains, which has been successfully declared for Chinese invention patents [7]. Laboratory tests showed that Cr10Mo1 steel has a critical chloride threshold level more than 10 times that of conventional carbon steel, exhibiting much higher corrosion resistance than most alloy steels and could bring about potential longer service life of concrete structures.

Basically, steel reinforcement embedded in concrete forms a very thin layer $(5 \sim 10 \mathrm{~nm})$ in the strong alkaline conditions of the concrete pore solution $(\mathrm{pH}>13)$, referred to as passive film [8], which acts a protective coat and forbids the metal from corroding. However, this passive layer can be destroyed due to concrete carbonation or chloride attack. Carbonation of concrete, as one of the main factors, reducing the initially high $\mathrm{pH}$ of the pore solution phase to values even lower than 9.0, could destroy the passive layer and then corrosion initiates. Carbonation-induced corrosion of carbon steel and its effects in concrete structure have been investigated extensively $[9,10]$. In contrast to that, there is little comparative study about carbonation-induced corrosion process of alloy corrosion-resistant steel. To partly fill this gap, this work presents a combined electrochemical and surface analytical investigation on the corrosion behaviour of passivated $\mathrm{Cr} 10 \mathrm{Mo} 1$ steel under the influence of carbonation, for an understanding of the carbonation-corrosion resistant behaviour of alloy corrosion-resistant steel.

\section{EXPERIMENTAL PROCEDURES}

\section{Materials}

Steel samples

Experimental materials were alloy corrosion-resistant HRB400 steel Cr10Mo1, designed by Research Institute of Jiangsu Shasteel Iron and Steel. The chemical composition (in \% by mass) was $0.01 \% \mathrm{C}, 0.49 \% \mathrm{Si}, 1.49 \% \mathrm{Mn}, 0.01 \% \mathrm{P}, 0.01 \% \mathrm{~S}, 0.06 \% \mathrm{~V}, 10.36 \% \mathrm{Cr}, 1.16 \% \mathrm{Mo}$, and the residual Fe.

Steel samples of $1 \mathrm{~cm}$ length were cut from ribbed rebars with a diameter of $25 \mathrm{~mm}$. The crosssection of steel samples was mechanically ground with grades 200, 600, 1000 and 2000 SiC emery papers successively, and polished with alumina paste up to $2.5 \mu \mathrm{m}$ grit to eliminate the heterogeneities of the steel surface. After polishing, the samples were degreased subsequently with alcohol, rinsed with distilled water and dried with a stream of air just before immersion to ensure their same initial surface state.

\section{Test solutions}

An alkaline solution with $0.03 \mathrm{M} \mathrm{Ca}(\mathrm{OH})_{2}$ (saturated) $+0.2 \mathrm{M} \mathrm{KOH}+0.1 \mathrm{M} \mathrm{NaOH}(\mathrm{pH} 13.3)$, prepared with analytical grade chemicals and Millipore water $(18.2 \mathrm{M} \Omega \cdot \mathrm{cm})$, was used to simulate the electrolyte in fresh concrete pores. Firstly, the steel samples were kept in the initial solution (pH 13.3) for 10 days to allow the formation of stable passive films on the exposed rebar cross sections [11]. Then the $\mathrm{pH}$ values of the initial alkaline solution were adjusted to $12.0,10.5$, and 9.0 by progressively adding $\mathrm{NaHCO}_{3}$ powder, to simulate the gradual carbonation process of concrete pore solutions. With the $\mathrm{pH}$ dropping from 13.3 to 9.0, the samples were kept for 10 days at each $\mathrm{pH}$ condition. The $\mathrm{pH}$ of the solutions was carefully checked and monitored throughout by a Methron $\mathrm{pH}$ meter.

\section{Electrochemical measurements}

Changes in the surface film formed with immersion time at different $\mathrm{pH}$ values was monitored by electrochemical tests. The electrochemical tests, including linear polarization resistance (LPR) and electrochemical impedance spectroscopy (EIS), were performed at room temperature $\left(25^{\circ} \mathrm{C}\right)$ and under natural aeration in a classical electrochemical cell with three electrodes, where steel sample as the working electrode was installed with an exposed working area of $1 \mathrm{~cm}^{2}$, the reference electrode was a saturated calomel electrode (SCE, all electrode potentials reported in this study were referred to SCE), and platinum counter electrode was also used. 
LPR measurements were carried out with polarization within $\pm 20 \mathrm{mV}$ from the open-circuit potential in the anodic direction with a scan rate of $0.166 \mathrm{mV} / \mathrm{s}$. The EIS response was recorded, which closely followed LPR, in a frequency range from $10^{4} \mathrm{~Hz}$ down to $10^{-2} \mathrm{~Hz}$ with the applied AC amplitude of $10 \mathrm{mV}$ at OCP. There were 3 replicates for each specimen. The equipment used was a PARSTAT 4000 electrochemical system (Princeton Applied Research Inc., Oakridge, TN).

Surface analysis

Steel samples immersed in the test solutions of different $\mathrm{pH}$ for 7 days at OCP were withdrawn, rinsed with distilled water and dried with ethanol after removing the surface residues by ultrasonic cleaning, then kept in a vacuum dryer.

The analysis of the film composition was conducted by X ray photoelectron spectroscopy (XPS). An PHI Quantera SXM X-ray photoelectron spectrometer equipped with a monochromatic Al Ka radiation source $(\mathrm{E}=1486.6 \mathrm{eV})$, a hemispherical electron analyzer operating at a pass energy of 55 $\mathrm{eV}$ and an analytical chamber with a base pressure of $10^{-7} \mathrm{~Pa}$, was used to collect XPS spectra. The depth profile information was obtained by sputtering the specimens with a scanning argon-ion gun operating at ion energy of $2 \mathrm{keV}$. The sputtering rate was estimated to be about $0.055 \mathrm{~nm} \cdot \mathrm{s}^{-1}$. The spectra were calibrated by setting the main line for the $\mathrm{C}$ 1s signal of adventitious carbon to 284.6 eV. All XPS spectral analysis was performed by the commercial software XPSpeak version 4.1, which contained the Shirley background subtraction and Gaussian-Lorentzian tail function for better spectra fitting.

\section{Results and discussion}

Surface analysis (XPS)

The chemical composition of the surface film on the corrosion-resistant steel in test solutions of different $\mathrm{pH}$ was examined by XPS. The results show that the mainly composition of the film formed on the steel is $\mathrm{Fe}, \mathrm{Cr}$ and $\mathrm{O}$, indicating that the primary constituents are $\mathrm{Fe}$ and $\mathrm{Cr}$ oxides. Obtained spectra of all elements were separated into some chemical states which are most probable components needed for corresponding chemical assignments using a deconvolution software XPSpeak version 4.1 (Fig. 1), based on the binding energies according to the Handbook of X-ray photoelectron spectroscopy [12] and previous reports [13]. According to the deconvoluting results, the $\mathrm{Fe} 2 \mathrm{p}_{3 / 2}$ signals show the presence of three components, including metallic state (Fe $\mathrm{Fet}_{\text {me }} 706.5$ $\mathrm{eV}), \mathrm{Fe}^{2+}$ in oxide form $(\mathrm{FeO}, 709.5 \mathrm{eV})$ and $\mathrm{Fe}^{3+}$ in oxide $\left(\mathrm{Fe}_{2} \mathrm{O}_{3}, 710.6 \mathrm{eV}\right)$ and hydroxide $\left.\left(\mathrm{FeOOH} / \mathrm{Fe}(\mathrm{OH})_{3}\right), 712.0 \mathrm{eV}\right)$ form. The $\mathrm{Cr} 2 \mathrm{p}_{3 / 2}$ spectra contain three different contributions which are assigned to $\mathrm{Cr}_{\text {met }}(574.1 \mathrm{eV}), \mathrm{Cr}_{2} \mathrm{O}_{3}(576.3 \mathrm{eV})$ along with $\mathrm{CrOOH} / \mathrm{Cr}(\mathrm{OH})_{3}(577.1 \mathrm{eV})$. The intensities of the $\mathrm{Cr}_{2} \mathrm{O}_{3}$ states are apparently higher than that of $\mathrm{CrOOH} / \mathrm{Cr}(\mathrm{OH})_{3}$, indicating $\mathrm{Cr}_{2} \mathrm{O}_{3}$ is the dominant $\mathrm{Cr}$ species in the passive film formed on the steel. Two contributions were detected in the oxygen $\mathrm{O}$ 1s spectrum: the first at $530.2 \mathrm{eV}$ assigned to oxygen in oxides $\left(\mathrm{O}^{2-}\right)$ and the second at $531.8 \mathrm{eV}$ to metal-bonded hydroxide groups $\left(\mathrm{OH}^{-}\right)$, corresponding to the formation of iron oxides and hydroxides in the passive film.

Fig. 2 shows the composition profile (for atomic ration of $\mathrm{Cr} / \mathrm{Fe}, \mathrm{Fe}^{2+} / \mathrm{Fe}^{3+}, \mathrm{Fe}_{\text {hy }} / \mathrm{Fe}_{\text {ox }}$ and $\left.\mathrm{Cr}_{\text {hy }} / \mathrm{Cr}_{\mathrm{ox}}\right)$ at various sputtered depths of the surface film on the steel in all test solutions, obtained from quantitative XPS analysis according to the peak intensity of components. As illustrated in Fig. 2(a), with increasing sputtering depth, the $\mathrm{Cr} / \mathrm{Fe}$ ration is very small at first but has a marked increase, and then decreases gradually at about $4 \mathrm{~nm}$, to near the content ratio of $\mathrm{Cr} / \mathrm{Fe}$ in metal substrate at $6 \mathrm{~nm}$. This important feature reveals that the constituents within passive film of the steel varies with depth into the layer: the inner region that is adjacent to the metal substrate is a $\mathrm{Cr}$ species concentrated layer, while the outer layer is mostly composed of Fe oxides and hydroxides, which is consistent with the depth profile of the Fe-based film layer on carbon steel suggested by Ghods et al [8]. It is noteworthy that, with carbonation progressing, the Cr content in the film shows an increasing evolution, indicating there is a gradual enrichment of the Cr components in the surface film. This fact may account for the higher stability of $\mathrm{Cr}$ oxides insensitive to $\mathrm{pH}$ values, and the higher dissolution rate of $\mathrm{Fe}$ oxides at the film/solution interface when the $\mathrm{pH}$ drops according 
to the Pourbaix diagrams [14]. The components change of the surface film has an important influence on electrochemical behaviour of the steel, as suggested by the follow electrochemical measurements.

Under gradual carbonation, $\mathrm{Fe}^{2+}{ }_{\text {ox }}$ decreases significantly at the same depth into the film (Fig. 2(b)) while the $\mathrm{Fe}^{3+}$ hy undergoes a growth (Fig. 2(c)), revealing the further oxidization of Fe species in the film. Thus, it could be deduced that when the surface film is exposed to lower $\mathrm{pH}, \mathrm{Fe}_{2} \mathrm{O}_{3}$ decomposes gradually, transforming to hydrates $\mathrm{FeOOH} / \mathrm{Fe}(\mathrm{OH})_{3}$. This causes the $\mathrm{Fe}_{2} \mathrm{O}_{3}$ layer becomes less and less dense, and facilitates the diffusion of surrounding oxygen into the layer, which induces progressive oxidation of $\mathrm{FeO}\left(\mathrm{Fe}_{3} \mathrm{O}_{4}\right)$ to $\mathrm{Fe}_{2} \mathrm{O}_{3}$, corresponding to a gradual decrease in $\mathrm{Fe}^{2+}$ content in the passive film. Compared to Fe oxides, Fe hydroxides are porous and almost unprotective [15]. So, carbonation could reduce the protection of the Fe oxides layer. Similar to the $\mathrm{Fe}^{3+}$ hy content evolution, $\mathrm{Cr}^{3+}$ hy concentration in $\mathrm{Cr}$ species also has a constant increase in the film as the $\mathrm{pH}$ dropping, but the change is moderate (Fig. 2(d)). This suggests that Cr oxides also can be hydrated to corresponding hydroxides like Fe oxides by the action of carbonation.
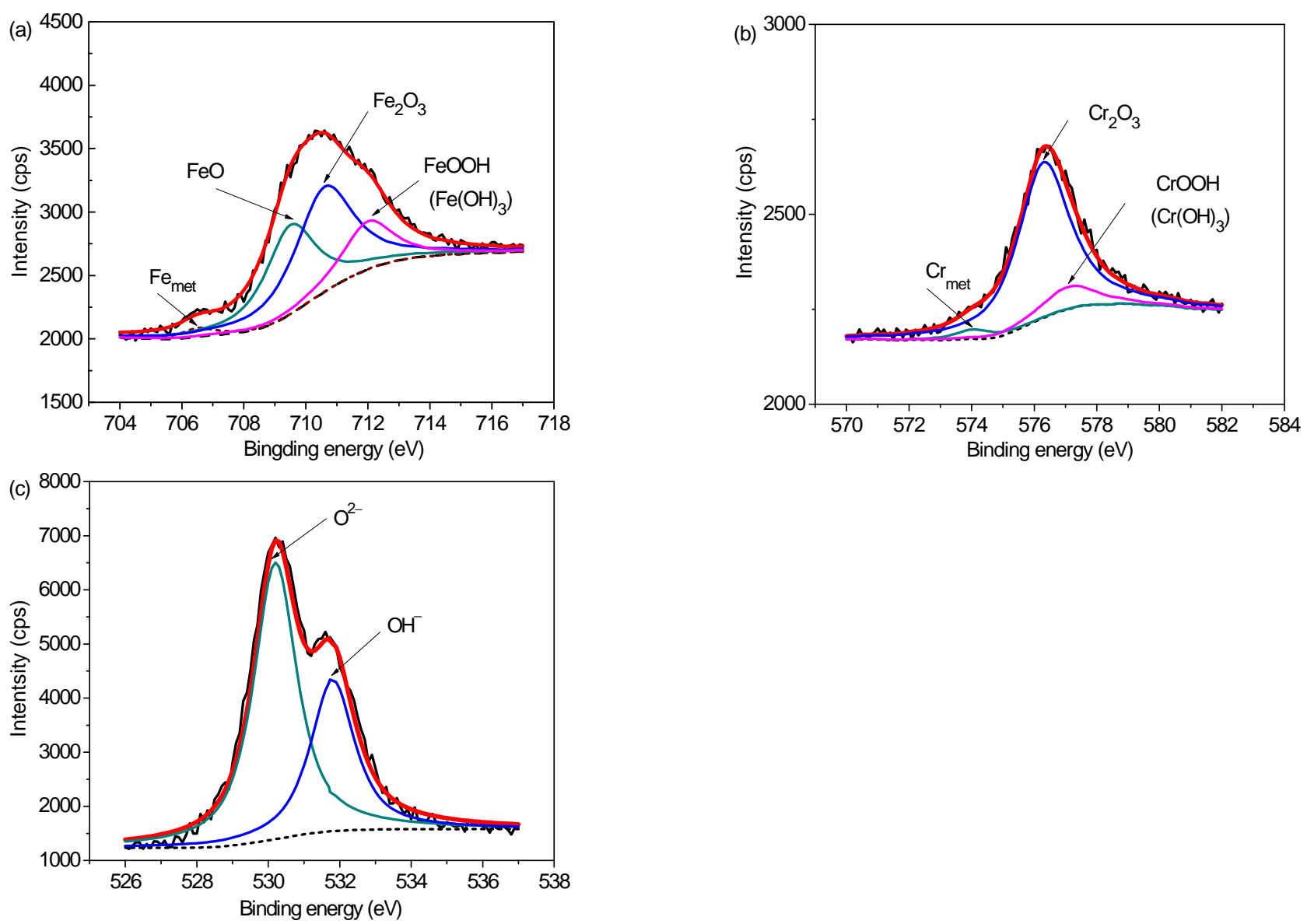

Fig. 1 Deconvolucion of the Fe $2 p_{3 / 2}, \mathrm{Cr} 2 \mathrm{p}_{3 / 2}$ and O 1s XPS spectra detected for the surface film formed on the corrosion-resistant steel after $7 \mathrm{~d}$ immersion in solutions of $\mathrm{pH}$ 13.3: (a) $\mathrm{Fe} 2 \mathrm{p}_{3 / 2}$ spectra; (b) $\mathrm{Cr}_{2} \mathrm{p}_{3 / 2}$ spectra; (c) $\mathrm{O} 1 \mathrm{~s}$ spectra 

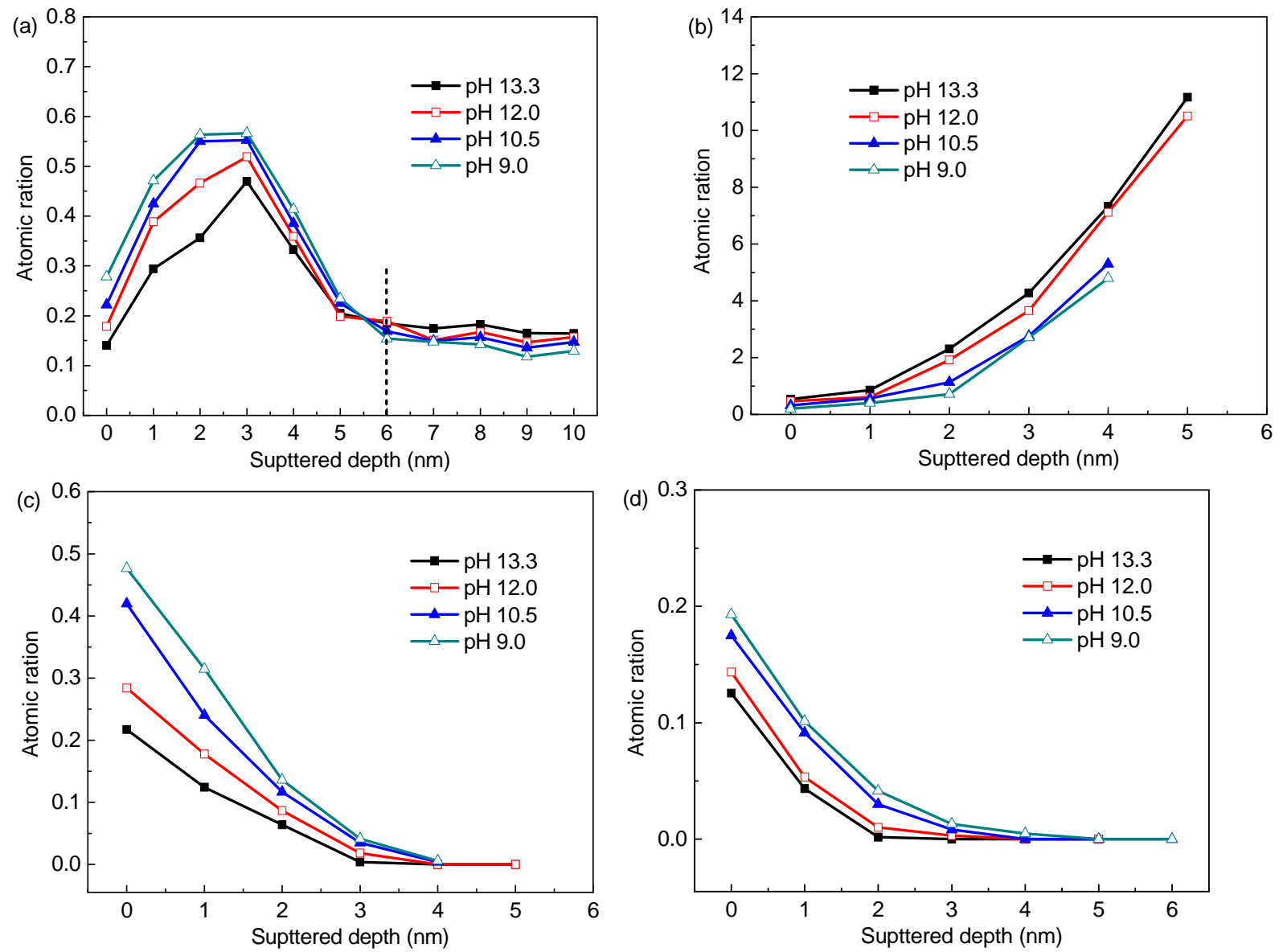

Fig. 2 Composition depth profiles obtained from XPS analysis for the surface film formed on the steel in test solutions of different $\mathrm{pH}$ (a) $\mathrm{Cr} / \mathrm{Fe}$; (b) $\mathrm{Fe}^{2+} / \mathrm{Fe}^{3+}$; (c) $\mathrm{Fe}_{\text {hy }} / \mathrm{Fe}_{\text {ox }}$; (d) $\mathrm{Cr}_{\text {hy }} / \mathrm{Cr}_{\text {ox }}$

\section{Electrochemical measurements}

\section{Linear polarization resistance}

Linear polarization resistance (LPR) monitoring is a non-destructive technique to measure the corrosion current density of reinforcing steel and evaluate its condition. This technique has been discussed in detail in many works [16].
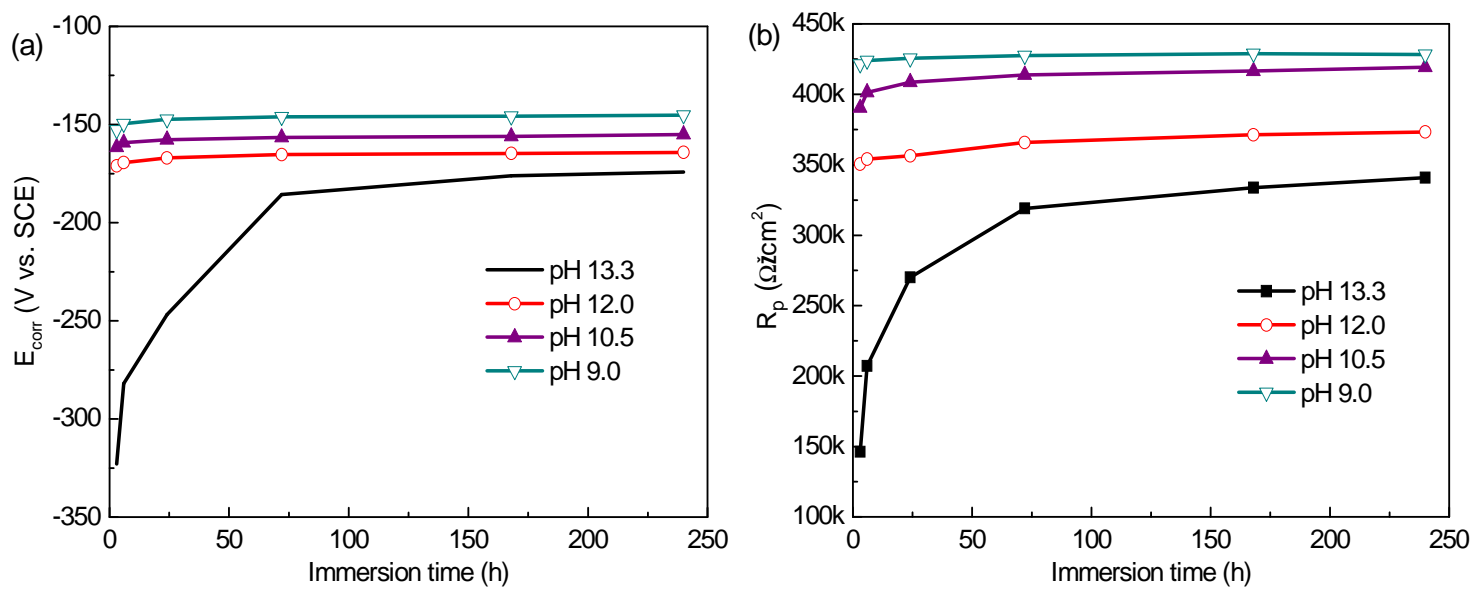

Fig. 3 The corrosion potential $\left(\mathrm{E}_{\mathrm{corr}}\right)$ and polarization resistance $\left(\mathrm{R}_{\mathrm{p}}\right)$ of the steel as a function of time in test solutions of different $\mathrm{pH}$ : (a) $\mathrm{E}_{\text {corr }}$; (b) $\mathrm{R}_{\mathrm{p}}$

The corrosion potential $\left(\mathrm{E}_{\text {corr }}\right)$ and polarization resistance $\left(\mathrm{R}_{\mathrm{p}}\right)$ values obtained from the LPR curves, of the corrosion-resistant steel in all test solutions against time ( $3 \mathrm{~h}, 6 \mathrm{~h}, 1 \mathrm{~d}, 3 \mathrm{~d}, 7 \mathrm{~d}, 10 \mathrm{~d})$ are shown in Fig. 3. The results showed that both $E_{\text {corr }}$ and $R_{p}$ values are affected by exposition conditions. Under gradual carbonation, at the beginning of exposure, $\mathrm{E}_{\text {corr }}$ values of the steel have 
continuous rising (notably during the first $3 \mathrm{~d}$ of immersion) and tends to remain stable after $7 \mathrm{~d}$ immersion. At $10 \mathrm{~d}$ immersion time, Ecorr has variations from -200 to $-150 \mathrm{mV}$ vs. SCE, indicating good passivation state [17] of the steel at all $\mathrm{pH}$ values. $\mathrm{R}_{\mathrm{p}}$ shows similar evolution as $\mathrm{E}_{\mathrm{corr}}$, has enhanced values at low $\mathrm{pH}$, increasing by $1 / 4$ when $\mathrm{pH}$ falls from 13.3 to 9.0 . Higher the $\mathrm{R}_{\mathrm{p}}$ value, more difficult the corrosion process [18]. So carbonation (in the alkaline range) does not initiate and promote the corrosion of the steel, but contrary to what might be supposed, it causes a sedater corrosion rate for the steel. In another vein, concrete carbonation process, has no negative effects on the corrosion resistance of the steel (at least if the environment is not contaminated by aggressive anions). This is a considerable improvement for $\mathrm{Cr} 10 \mathrm{Mo} 1$ steel compared to carbon steel, which enter in the corrosion domain when $\mathrm{pH}$ below 10.5 [14]. This behaviour should be attributed to the enrichment of Cr oxides, which improves the stability and protection of the film, resulting in a less defective layer with more resistant to corrosion.

\section{Electrochemical impedance spectroscopy}

Fig. 4 shows the Electrochemical impedance spectroscopy (EIS) in the Nyquist and Bode plots form obtained for the steel after $7 \mathrm{~d}$ immersion time in solutions of varying $\mathrm{pH}$ from 13.3 to 9.0. It is evident that the capacitance arc magnitude and overall impedance value of the steel have significant increasing following the $\mathrm{pH}$ dropping, indicating the steel at lower $\mathrm{pH}$ exhibiting more corrosion-resistant, which is in good agreement with the LPR results.

For more detailed information on the electrochemical processes associated with the surface films with $\mathrm{pH}$ variation, the EIS results were fitted using equivalent circuits. Based on some trials and literatures support $[19,20]$, the equivalent circuit as depicted in Fig. 5 was adopted to fit the experimental data, which provided a right fitting with minimal error.

Constant phase element (CPE) is used for the description of frequency dispersion behaviour corresponding to metal surface covered by heterogeneous layer with some defects. The impedance of the CPE is defined by Eq. (1)

$$
Z_{C P E}=\frac{1}{(\Psi)_{0}(j w)^{n}}
$$

where the meaning $\mathrm{Y}_{0}, \mathrm{j}, \mathrm{w}$ and $\mathrm{n}$ is similar with that of most literatures [19,20].

For the meaning of the circuit elements in this circuit model, the following physical interpretation are adopted $[19,20]$ : The resistance connected in series with two time constants corresponds to the ohmic resistance of the solution $\left(\mathrm{R}_{\mathrm{sol}}\right)$, which changes with ion concentrations of the test solutions. The high frequency time constant $\left(\mathrm{R}_{1}, \mathrm{CPE}_{1}\right)$ can be attributed to the charge transfer process in the active surface areas (film defects/pores) and it is represented by the charge transfer resistance $\left(\mathrm{R}_{1}\right)$ coupled with the double layer capacitance (simulated by $\mathrm{CPE}_{1}$ ). The low frequency time constant $\left(\mathrm{R}_{2}, \mathrm{CPE}_{2}\right)$ was assigned to the redox process taking place in the areas covered with the passive film (protective oxide) and it is composed by the passive film capacitance $\left(\mathrm{CPE}_{2}\right)$ and the passive layer resistance $\left(\mathrm{CPE}_{2}\right)$.
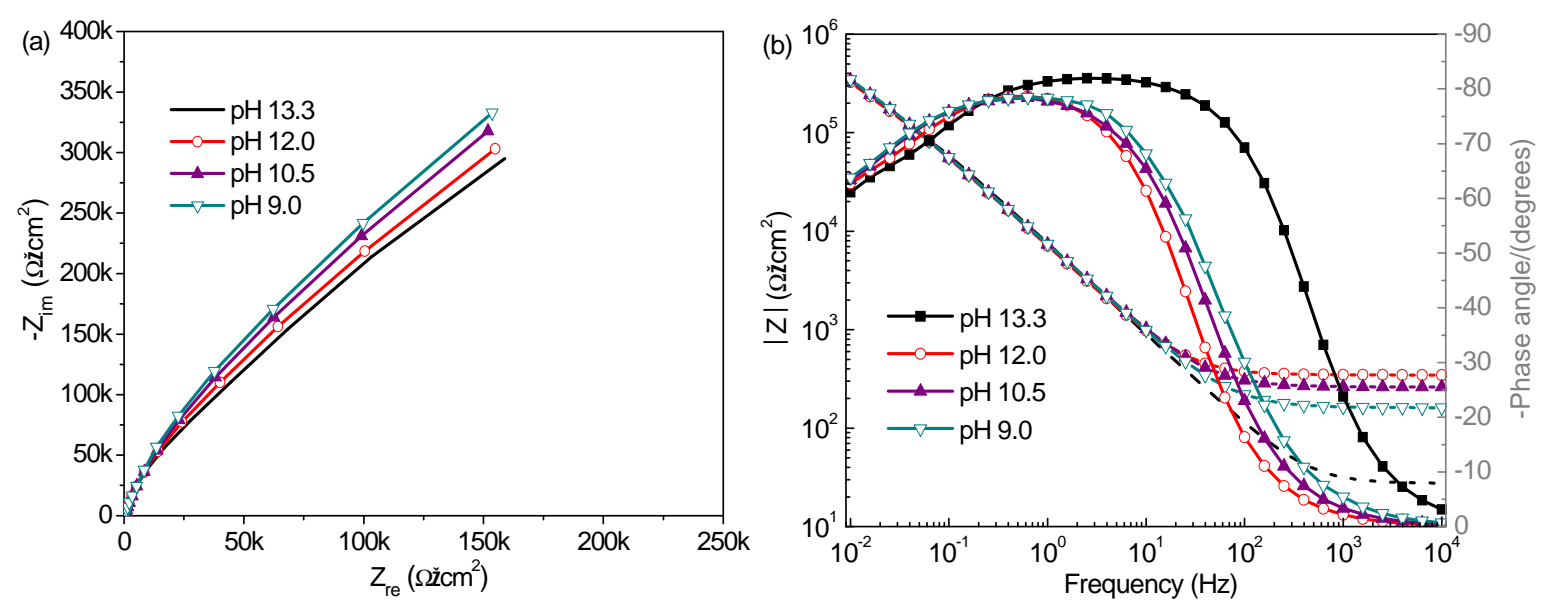

Fig. 4 Measured EIS of the steel in test solutions of different pH after $7 \mathrm{~d}$ immersion: (a) Nyquist plots; (b) Bode plots 


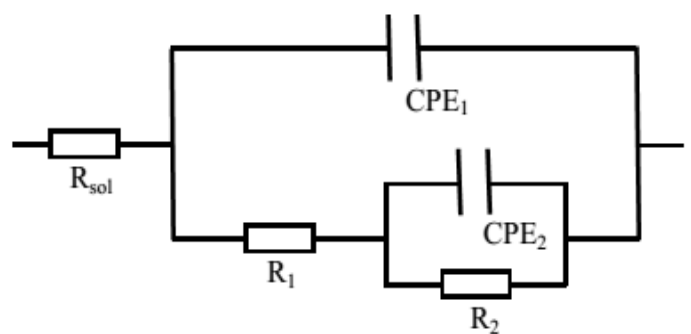

Fig. 5 Equivalent circuits used to model the experimental EIS data

Table 1 presents the fitting parameters (based on the circuit depicted in Fig. 5) for the experimental EIS data presented in Fig. 4. It can be observed that, no matter of carbonation degree, the $\mathrm{R}_{1}$ has high values above $300 \mathrm{k} \Omega \cdot \mathrm{cm}^{2}$, indicating the difficult charge transfer process. This obviously is ascribed to the stable $\mathrm{Cr}$ oxides concentrated layer formed on the metal, which as a barrier retards the $\mathrm{Fe}^{2+}$ in active areas to be released. The resistance $\mathrm{R}_{2}$ also shows higher values at lower $\mathrm{pH}$, evidencing the presence of a surface film that provides higher resistance to the flow of electrons in the redox processes. The $\mathrm{CPE}_{2}$ evolution with $\mathrm{pH}$ reveals the surface film formed at lower $\mathrm{pH}$ performs heightened capacitive behaviour. The $\mathrm{CPE}_{1}$ shows an upward tendency following the $\mathrm{pH}$ decreasing, suggesting the more significant dispersion effect of the double layer capacitance. This may be related to the film surface roughing as Fe species in the outer layer decomposes gradually under carbonation. Even so, the steel has more depressed electrochemical corrosion process at lower $\mathrm{pH}$ for its greater corrosion resistance (i.e. $\mathrm{R}_{1}+\mathrm{R}_{2}$ ).

Table 1 Fitting parameters for the experimental EIS data obtained for the steel in solutions of different $\mathrm{pH}$ after 7 d immersion

\begin{tabular}{|c|c|c|c|c|c|c|c|}
\hline \multirow[b]{2}{*}{$\mathrm{pH}$} & \multirow[b]{2}{*}{$\begin{array}{c}\mathrm{R}_{\mathrm{sol}} \\
(\Omega \cdot \mathrm{cm} \\
\left.{ }^{2}\right)\end{array}$} & \multirow[b]{2}{*}{$\begin{array}{c}\mathrm{R}_{1} \\
\left(\Omega \cdot \mathrm{cm}^{2}\right)\end{array}$} & \multicolumn{2}{|l|}{$\mathrm{CPE}_{1}$} & \multirow[b]{2}{*}{$\begin{array}{c}\mathrm{R}_{2} \\
\left(\Omega \cdot \mathrm{cm}^{2}\right)\end{array}$} & \multicolumn{2}{|c|}{$\mathrm{CPE}_{2}$} \\
\hline & & & $\begin{array}{c}\mathrm{Y}_{0} \\
\left(\Omega^{-1} \cdot \mathrm{cm}^{-2} \cdot \mathrm{s}^{\mathrm{n}}\right)\end{array}$ & $\mathrm{n}$ & & $\begin{array}{c}\mathrm{Y}_{0} \\
\left(\Omega^{-1} \cdot \mathrm{cm}^{-2} \cdot \mathrm{s}^{\mathrm{n}}\right)\end{array}$ & $\mathrm{n}$ \\
\hline 13.3 & 28.1 & $3.02 \times 10^{5}$ & $2.34 \times 10^{-5}$ & 0.92 & $11.84 \times 10^{5}$ & $1.76 \times 10^{-5}$ & 0.83 \\
\hline 12.0 & 346.4 & $4.34 \times 10^{5}$ & $2.48 \times 10^{-5}$ & 0.91 & $14.12 \times 10^{5}$ & $1.78 \times 10^{-5}$ & 0.82 \\
\hline 10.5 & 260.8 & $6.79 \times 10^{5}$ & $2.60 \times 10^{-5}$ & 0.89 & $17.92 \times 10^{5}$ & $1.71 \times 10^{-5}$ & 0.80 \\
\hline 9.0 & 160.5 & $8.12 \times 10^{5}$ & $2.64 \times 10^{-5}$ & 0.89 & $19.78 \times 10^{5}$ & $1.64 \times 10^{-5}$ & 0.81 \\
\hline
\end{tabular}

\section{CONCLUSIONS}

The corrosion behaviour of corrosion-resistant steel Cr10Mo1 subjected to carbonation attacking was investigated. The results proved that carbonation modify the chemical composition of the surface film on the steel, and then influences its electrochemical response.

Surface composition analysis performed by XPS revealed that the passive film formed on the corrosion-resistant steel consists of both $\mathrm{Fe}$ and $\mathrm{Cr}$ oxides/hydroxides, presenting a bilayer structure with an outer layer mainly containing $\mathrm{Fe}$ oxides (including $\mathrm{FeO}$ and $\mathrm{Fe}_{2} \mathrm{O}_{3}$ ) and hydroxides, and an inner layer highly enriched in $\mathrm{Cr}$ species. As $\mathrm{pH}$ falls, the $\mathrm{Fe}^{2+}$ and $\mathrm{Fe}^{3+}$ oxides decompose continuously and transform to porous $\mathrm{Fe}^{3+}$ hydroxides, while $\mathrm{Cr}$ species have a gradual enrichment in the film as more stable $\mathrm{Cr}$ oxides form on the metal. This has an important influence on the electrochemical behaviour of the steel.

LPR and EIS tests evidenced that corrosion-resistant steel maintains good passivation even if the $\mathrm{pH}$ drops to 9.0. Carbonation (within alkalinity range) does not deteriorate the passive film and initiate the corrosion of the steel, but bring about the steel more resistant to corrosion process, for compact and protective $\mathrm{Cr}$ oxides can maintain stable and get increasingly enriched in the inner 
layer, although protective $\mathrm{Fe}$ oxides in the outer layer suffer destruction. In media of low $\mathrm{pH}, \mathrm{Cr}$ species as a barrier on the metal, provide the steel good corrosion resistance.

\section{ACKNOWLEDGMENTS}

The authors gratefully acknowledge the financial support from National Basic Research Program of China (No. 2015CB655100), National Natural Science Foundation of China (No. 51278098 and 51308111), Industry-University-Research Cooperative innovation fund of Jiangsu Province (No. BY2013091), Transformation Projects of Major Scientific and Technological Achievements of Jiangsu Province (No. 85120000220).

\section{REFERENCES}

[1] Cabrera, J.G. 1996. Deterioration of concrete due to reinforcement steel corrosion. Cement and Concrete Composite 18(1): 47-59.

[2] Broomfield, J.P. 2007. Steel corrosion in concrete-Understanding, investigation and repair (2nd ed.). Taylor \& Francis, England: London.

[3] Revie, R.W. \& Uhlig, H.H. 2008. Corrosion and corrosion control-An introduction to corrosion science and engineering (4th ed.). John Wiley \& Sons, Inc., USA: New Jersey.

[4] MMFX Steel Corporation of America. 2002. MMFX steel 2002, product bulletin. http://www. mmfxsteel. com.

[5] Li, H.X. \& Yu, H. \& Zhou, T. \& Yin, B.L. \& Yin, S.J. \& Zhang Y.L. 2015. Effect of tin on the corrosion behavior of sea-water corrosion-resisting steel. Materials \& Design 84: 1-9.

[6] Chen, Y. \& Yang, Z.M. \& Wang H.M. 2012. Comprehensive properties of 400 MPa grade corrosion-resistant rebar. Journal of Iron and Steel Research, International 19(12): 48-52.

[7] Zhang, J.C. \& Huang, W.K. \& Li, Y. \& Ma, H. 2014. A highly corrosion-resistant reinforcing steel with high strength and its preparation technologies (in Chinese). Chinese Patent, CN103789677A.

[8] Ghods, P. \& Isgor, O. \& Bensebaa, B. F. \& Kingston, D. 2012. Angle-resolved XPS study of carbon steel passivity and chloride-induced depassivation in simulated concrete pore solution. Corrosion Science 58: 159-167.

[9] Badar, M. S. \& Kupwade-Patil, K. \& Bernal, S. A. \& Provis, J. L. \& Allouche, E. N. 2014. Corrosion of steel bars induced by accelerated carbonation in low and high calcium fly ash geopolymer concretes. Construction and Building Materials 61: 79-89.

[10] Angst, U. \& Elsener, B. \& Jamali, A. \& Adey, B. 2012. Concrete cover cracking owing to reinforcement corrosion-theoretical considerations and practical experience. Materials Corrosion 63(12): 1069-1077.

[11] Ghods, P. \& Isgor, O.B. \& McRae, G. \& Miller, T. 2009. The effect of concrete pore solution composition on the quality of passive oxide films on black steel reinforcement. Cement and Concrete Composite 31(1): 2-11

[12] Moulder, J.F. \& William, F.S. \&Peter, E.S. 1992. Handbook of X-ray Photoelectron Spectroscopy. Perkin-Elmer Corporation, USA.

[13] Guo, L.Q. \& Lin, M.C. \& Qiao, L.J. \& Volinsky, A.A. 2014. Duplex stainless steel passive film electrical properties studied by in situ current sensing atomic force microscopy. Corrosion Science 78: 55-62.

[14] Pourbaix, M. 1963. Atlas d'equilibres Electrochimiques. Gauthier-villars et Cie, Fance: Paris.

[15] Díez-Pérez, I. \& Vericat, C. \& Gorostiza, P. \& Sanz, F. 2006. The iron passive film breakdown in chloride media may be mediated by transient chloride-induced surface states located within the band gap. Electrochemistry Communications 8(4): 627-632.

[16] Lee, K.J. 2004. A mechanistic modeling of CO2 corrosion of mild steel in the presence of $\mathrm{H}_{2} \mathrm{~S}$. Ph.D. thesis. Ohio University, USA: Athens. 
[17] ASTM C876-91. 1999. Standard test method for half-cell potentials of uncoated reinforcing steel in concrete. ASTM International, USA: Philadelphia.

[18] Wu, J.W. \& Bai, D. \& Baker, A.P. \& Li, Z.H. \& Liu, X.B. 2013. Electrochemical techniques correlation study of on-line corrosion monitoring probes. Materials Corrosion 66(22): 143151.

[19] Liu, R. \& Jiang, L.H. \&Xu, J.X. \& Xiong, C.S. \& Song, Z.J. 2014. Influence of carbonation on chloride-induced reinforcement corrosion in simulated concrete pore solutions. Construction and Building Materials 56: 16-20.

[20] Abreu, C.M. \& Cristóbal, M.J. \& Losada, R. \& Nóvoa, X.R.\& Pena, G. \& Pérez, M.C. 2006. Long-term behaviour of AISI 304L passive layer in chloride containing medium. Electrochimica Acta 51(8-9): 1881-1890. 